\title{
Teachers' views on mathematical literacy and on their experiences as students of the course
}

\author{
Monde Mbekwa \\ School of Science and Mathematics Education, University of the Western Cape \\ mmbekwa@uwc.ac.za
}

This paper reports on a study undertaken at the University of the Western Cape with a class of 32 inservice teachers who had completed six months of an Advanced Certificate in Education (ACE) course in mathematical literacy in 2004. The teachers completed an evaluation questionnaire, which asked them about their common sense conception of mathematical literacy and their reflections on their student experiences in the first six months of the course at UWC. The study has found that some of these students' understanding of mathematical literacy corresponds to contradictory conceptions of mathematical literacy, which appear in the literature. Some expected that the course would be a watered-down version or easy mathematics whilst some viewed it as mathematics with applications in everyday life. Whilst some of the teachers perceived the course content to be "difficult", it is important to note that almost all the teachers, except those who dropped out, have completed and passed the course, which indicates that it was a worthwhile endeavour.

\section{Introduction}

I am a member of a three-person team that taught an Advanced Certificate in Education (ACE) course in mathematical literacy in 2004 at the University of the Western Cape, South Africa. Participants in the course were 32 in-service teachers out of an initial cohort of 140 course participants at four higher education institutions in the Western Cape.

The 140 teachers were selected by the Western Cape Education Department and registered, in equal groups of 35 , at the four higher education institutions in the Western Cape, namely the Universities of the Western Cape (UWC), Cape Town (UCT), Stellenbosch (US) and the newly established Cape Peninsula University of Technology (CPUT). The last mentioned institution was born out of the amalgamation of the two former technikons in the Western Cape, the Peninsula Technikon (PENTECH) and the Cape Technikon (CAPE TECH). These four universities had tendered as a consortium and won the right to offer the Advanced Certificate in Education in mathematical literacy to in-service teachers from Western Cape schools.

The major aim of the ACE in mathematical literacy is to prepare teachers to teach the new subject "mathematical literacy", introduced in the Further Education and Training (FET) phase (grades 10 to 12) in all South African secondary schools in 2006.

The course commenced in June 2004 and was scheduled to be completed in 2006, the year in which the new subject, mathematical literacy, was going to be introduced into South African high schools. The fact that only 140 teachers in the Western Cape started the course, and that it was scheduled for completion in the year in which mathematical literacy was planned to be introduced, eloquently illustrates the lack of readiness of the Department of Education to implement its own policy innovations.

The National Department of Education declared that, as from 2006, mathematical literacy would be a compulsory subject for all those learners in the FET band who do not take mathematics as a subject. In anticipation of this, the education and training of teachers in mathematical literacy would be an imperative, considering the vast numbers of learners who are not doing mathematics as a subject at school.

Clearly, it makes sense to train and educate teachers who are not teaching mathematics, in addition to teachers of mathematics, so as to have an adequate number of teachers to teach mathematical literacy to the huge numbers of learners who would not be taking mathematics in 2006. It is illuminative of the enormity of the task at hand to note the report of the National Minister of Education, Naledi Pandor (2004), on the final results of the senior certificate at the end of 2004. She reported that, of the 471080 learners who wrote the grade 12 examinations in 2004, 283744 or $57.2 \%$ wrote mathematics. This implies that $42,8 \%$ did not write mathematics, which is close to the number of those who wrote mathematics. 


\section{Monde Mbekwa}

One can imagine what the situation would be like if these figures are extended to all learners who would not be doing mathematics in the FET phase, and consequently, would have to do mathematical literacy. It stands to reason that it will be beyond the capacity of the present core of qualified mathematics teachers to cope with the total population of learners at school. Hence the recruitment of tens of thousands more teachers would be imperative to cope with this new demand. Most of these teachers, who need training, will have to be recruited from nonmathematical disciplines because it would be impossible for the existing mathematics teachers to teach both mathematics and mathematical literacy. It might even be necessary to recruit from beyond the borders of South Africa. It is in the context of this new reality and the need to ensure the availability of teachers who are qualified to teach the new subject that the National Department of Education is embarking on this retraining exercise.

The introduction of this new subject in the South African schooling system forms part of the momentum of curriculum reform propelled by the introduction of C2005 in the 1990s and its subsequent revision through the Revised Curriculum Statement in the 2000s. Because most of the teachers who will be required to teach mathematical literacy are not practising mathematics teachers, they will need both subject content knowledge and pedagogical content knowledge. It is obvious that these teachers will also need to have an understanding of mathematical concepts, and knowledge of mathematical algorithms and problem solving skills. The challenge for teacher educators would be to ensure that teachers develop these skills and knowledge. As Adler (2003: 4) has put it:

There is little contention that teachers need to know the subject matter they are teaching, and moreover, that they need to know how to present this clearly to learners.

\section{The nature of the course at UWC in 2004}

The University of the Western Cape (UWC) registered 35 students on 20 June 2004, to commence studies at the beginning of the second semester in July 2004.

It was planned for these students to complete the course in four semesters, implying that the first group would finish in June of 2006 and thus graduate in the UWC case in September 2006. There were 35 students who registered in June
2004 but by the end of the year three had left the course.

Hence at the commencement of examinations in November, 33 had finished the semester, having been joined by one student who registered late.

The curriculum designed at UWC for the certificate comprises the following components: Mathematical Literacy for Teaching, Mathematics Education, Computer Studies and HIV/AIDS Education and Counselling. The Computer Studies and HIV/AIDS modules were added to all ACE courses offered by UWC so that students could complete the ten modules required to qualify for the ACE course. The first component of the course, Mathematical Literacy for Teaching, comprises four modules and the other components, two modules each to make up a total of ten modules. The decision taken by the lecturers, especially for the Mathematical Literacy for Teaching component, was to deal with one learning outcome of the National Curriculum Statement per semester. The learning outcomes as indicated in the mathematical literacy curriculum, are the following: (1) Number and Operations in Context (2) Functional Relationships (3) Space, Shape and Measurement and (4) Data Handling.

The focus of this paper is on the UWC module Mathematical Literacy for Teaching 113, which deals with the first learning outcome of mathematical literacy, namely Number and Operations in Context as stated in the National Curriculum Statement. The National Curriculum Statement for mathematical literacy explains the focus of this outcome as follows:

The focus of this learning outcome is on the investigation and solution of problems that require a sound understanding of numbers and their use in calculations, especially in financial contexts, ranging from personal to international issues.... Learners should develop sound estimation and mental calculation skills and a facility in using equivalent forms to simplify calculations. Proper conceptual understanding will be required to enable learners to use calculators appropriately and effectively. (DoE, 2003: 11)

The curriculum designed at UWC for this learning outcome includes the following topics: integers; fractions; ratio, rate and proportion; formula construction and substitution in formulae; exponents, scientific notation and compound interest. After the completion of the module, I wanted to gauge the students' common sense 
understanding of mathematical literacy, and also to find out how they experienced the course.

\section{The research question}

The main aim of this study was to gauge students' common sense understanding of the notion of mathematical literacy, which they are expected to teach at the end of their study, and their motivations and perceptions about the course. This study aimed at responding to the following research questions:

- What are teachers' motivations for registering for the ACE in mathematical literacy?

- What is the teachers' common sense understanding of mathematical literacy?

- What are the teachers' views of their experiences as students of mathematical literacy?

- How do the teachers evaluate the course?

\section{Literature review}

The South African National Department of Education in its National Curriculum Statement (2003: 10) conceives mathematical literacy as being:

... driven by life-related applications of mathematics. It enables learners to develop the ability and confidence to think numerically and spatially in order to interpret and critically analyse everyday situations and to solve problems.

The International Programme Committee for ICMI Study 14 (2002) condenses the understanding of mathematical literacy cited above when it states that mathematical literacy belongs to the domain of "applications and modelling of mathematics". This means that mathematical literacy implies modelling, which refers to the translation of reality to mathematical models and "application" implies the use of mathematical models to solve real life problems. One can observe the dual mathematical implication "modelling" $\Rightarrow$ moving from reality $\rightarrow$ to mathematics and "applications" $\Rightarrow$ moving from mathematics $\rightarrow$ to reality.

In articulating the purpose of mathematical literacy, the NCS states that mathematical literacy "will develop the use of basic mathematical skills in critically analysing situations and critically solving everyday problems." (DoE, 2003: 10).

This understanding of mathematical literacy characterises it as having an important application or functional use in real life. Hence it is not viewed as being mathematics for its own sake but as mathematics having relevance in contextual problem solving (Romberg, 2001; OECD, 2001). This is also what Jablonka (2003) refers to as Mathematical Literacy for Developing Human Capital.

Whilst there is a paucity of literature on mathematical literacy and also little consensus on the definition of mathematical literacy, all definitions of mathematical literacy provided in the literature highlight the functional dimension of mathematics by focusing on its application in the lives of citizens.

In addition to the idea of mathematical literacy having a critical application dimension, it is also seen as having an important role in encouraging people to engage in and understand mathematics, implying that mathematics does not only have an aesthetic value but also a use value. In this sense then, one can view mathematical literacy as mathematics with concrete and practical value in day-to-day existence. It can also be understood as literacy in the same way as literacy in a language, which is indispensable in a world in which language is a tool for sense-making and social intercourse. In this sense, a mathematically literate person is one who understands the language of mathematics, with its nuances and its applications, as a communication tool.

The view of mathematical literacy as mathematics with a utility value is borne out by PISA (The Programme for International Student Assessment), which views mathematical literacy as:

...the capacity to identify, understand and engage in mathematics, and to make well founded judgements about the role that mathematics plays in an individual's current and future private life, occupational life, social life with peers and relatives, and life as a constructive, concerned and reflective citizen. (OECD, 2001: 22)

Hence PISA proposes that mathematical literacy should be seen not only as a tool for solving life problems but also as a tool to understand a mathematised world.

Lastly, the Mathematical Council of the Alberta Teachers' Association views mathematical literacy as:

- Connecting mathematics to the real world

- Using mathematics appropriately in a variety of contexts 


\section{Monde Mbekwa}

- Communicating using the richness of mathematics

- Synthesising, analysing, and evaluating the mathematical thinking of others

- Appreciating the utility and elegance of mathematics

- Understanding and being conscious of what has been learned mathematically (MCATA, 2002: 2)

The above conception of mathematical literacy emphasises both its contextual connectedness and its utility value as an instrument to appreciate the elegance of mathematics.

\section{Methodology}

\section{The sample and data collection}

At the beginning of the 2005 academic year, 32 questionnaires were issued to the teachers who had registered for the ACE course in mathematical literacy in 2004. Students took the questionnaires away to complete at home. Of these, 20 questionnaires were completed and returned.

Eight questions appear in the questionnaire ranging from why the students applied to do the course, what their understanding of mathematical

\begin{tabular}{|c|c|c|c|c|}
\hline Teacher & $\begin{array}{l}\text { Teaching } \\
\text { experience in } \\
\text { years }\end{array}$ & Subjects taught in 2004 & Grades taught & $\begin{array}{l}\text { Highest } \\
\text { qualification in } \\
\text { maths }\end{array}$ \\
\hline 1 & 9 & Technology/Science & 8,9 & Matric \\
\hline 2 & 15 & Technology/Needlework & 11,12 & Matric \\
\hline 3 & 12 & Maths/Life orientation & 8,10 & $\mathrm{DE} \mathrm{III}^{1}$ \\
\hline 4 & 12 & Maths/History & 8 & DE III \\
\hline 5 & 18 & Economics/Accounting & $9,10,11,12$ & Matric $^{2}$ \\
\hline 6 & 21 & Biology & 11,12 & PTD III $^{3}$ \\
\hline 7 & 18 & Technical Subjects & $10,11,12$ & $\mathrm{~N} 4^{4}$ \\
\hline 8 & 16 & EMS & 8,9 & \\
\hline 9 & 15 & Geography & 11 & 12 \\
\hline 10 & 8 & $\begin{array}{l}\text { Metal Work/Technical } \\
\text { Drawing }\end{array}$ & $8,9,10,11,12$ & Math 1 \\
\hline 11 & 14 & Accounting & 10,11 & Grade 9 \\
\hline 12 & 14 & $\begin{array}{l}\text { EMS/Economics/Bus. } \\
\text { Econ. }\end{array}$ & $8,10,11,12$ & Matric \\
\hline 13 & 15 & $\begin{array}{l}\text { Needle } \\
\text { Work/Technology/Travel } \\
\& \text { Tourism }\end{array}$ & $8,10,11 \& 12$ & College Yr 1. \\
\hline 14 & 11 & Geography/English & 9,10 & Matric \\
\hline 15 & 15 & History/Arts\& Culture & 9,12 & Matric \\
\hline 16 & 12 & Maths/Science & 9 & $\mathrm{HDE} \mathrm{IV}^{5}$ \\
\hline 17 & 17 & Maths/Science & 8 & HDE IV \\
\hline 18 & 20 & Maths & 9,10 & $\begin{array}{l}\text { Diploma in } \\
\text { Education }\end{array}$ \\
\hline 19 & 19 & Accounting/EMS & $8,9,10,11,12$ & Math 1 \\
\hline 20 & 15 & Afrikaans & $9,10,11,12$ & Matric \\
\hline
\end{tabular}

Table 1: Profiles of questionnaire respondents

\footnotetext{
1 DE 111 is a teaching qualification: a three-year post grade 12 teaching qualification.

2 Matric is grade 12.

3 PTD is a Primary Teachers' Diploma: a three-year post grade 12 teaching qualification.

${ }^{4} \mathrm{~N} 4$ is a one-year post grade 12 qualification obtained at a technical college.

${ }^{5} \mathrm{HDE}$ is a four-year post grade 12 teaching qualification formerly obtained at a university.
} 
literacy was, their expectations of the course, and experiences during mathematical literacy classes to what their attitude was towards the examination and their course assignments.

The profiles of the teachers who responded to the questionnaire appear in Table 1 on the preceding page. From this data, one can see that these are experienced teachers with the lowest experience of teaching being eight years.

One can also see that of the six (30\%) teachers who have a teaching qualification in mathematics, there are five teachers (25\%) who taught mathematics in 2004. There were 17 teachers with matric or grade12 mathematics, a percentage of more that $85 \%$. Of these, two had a first year university mathematics qualification.

Only one teacher indicated that he or she had grade nine as the highest qualification in mathematics. From this data, one could then expect that more than $95 \%$ of the teachers, very close to the total sample, had a reasonable familiarity with high school mathematical concepts.

\section{Data analysis and findings}

I analysed all the responses to the questions and clustered the teachers' responses according to the questions they responded to, and then identified trends in their responses.

Here, I report on the teachers' responses to questions relating to reasons for registering for the course, the teachers' common sense understanding of mathematical literacy, their understanding of the course content and their attitude towards examinations and the formative assessment tasks. I am reporting on responses to these questions because they are closely tied to the research questions.

\section{Motivations for applying}

On the question why students chose to apply for the course, seven out of the 20 students (i.e. 35\%) saw this as an opportunity to be able to teach mathematical literacy. They answered that they joined the course: "To teach mathematical literacy." Four (20\%) saw this as an opportunity to teach mathematics, e.g. "Ek wil graag meer betrokke raak by die gee van Wiskunde." II want to be more involved in the teaching of mathematics.]

Some $(25 \%)$ saw it as an opportunity to improve themselves or to broaden their mathematical knowledge, e.g "I had to retrain myself in a new field. Mathematics literacy seemed to be a fresh difference to what I normally do."

The rest of the students (15\%) saw this as an opportunity to secure their jobs, e.g. "There was an opportunity to study. To secure my job in the Mathematics Department."

\section{Common sense understanding of mathematical literacy}

Responses to the question on the teachers' common sense conception of mathematical literacy can be categorised into two areas: (1) The "functionalist" view, which regards mathematical literacy as that type of mathematics that finds application in people's lives. As some teachers put it: "Mathematics is part of every person's life. People must handle their own finances and do calculations. When you do that you are mathematically literate." About $30 \%$ of the respondents have this view of mathematical literacy, which coincides with the view that mathematical literacy has to do with contextual problems in people's daily lives. (2) Another view, which teachers hold, is that mathematical literacy is a simplified or an easier version of the mathematics that learners do at school. As they put it: "Basic knowledge of mathematics" or "An easy version of mathematics. Just to help learners in the real world."

The latter response is a combination of what I regard as a functional understanding of mathematical literacy and the alternative understanding that mathematical literacy is no different from school-going mathematics except that it is easier than mathematics. I regard this conception of mathematical literacy as a lower level conception of mathematical literacy. Many mathematics educators agree that mathematical literacy is not a watered down version of mathematics and that it demands the same rigour that is exercised in the pursuit of an understanding of formal mathematics. Madison (2005) underscores the seriousness with which mathematical literacy (which he refers to as Quantitative Literacy) ought to be dealt when he states:

There can be no doubt that QL (Quantitative Literacy) is difficult...

The difficulty of QL, however, is rooted in its sophisticated uses of elementary mathematics and their immersion in extraneous, varied and possibly confusing terminology. Using mathematics in multiple and unpredictable contexts requires both an 


\section{Monde Mbekwa}

understanding of mathematical concepts and practice at retrieving and applying them. Often contexts are replete with the language of science, statistics, economics or engineering. Relevant information may be ambiguous or hidden. Sorting all this out, modelling with mathematics or statistics, doing the mathematics and interpreting the results is challenging indeed. (Madison, 2005: np)

Brombacher (2005) undergirds the view that mathematical literacy is not easy mathematics when he writes in the Cape Times:

What I really worry about is the possibility that mathematical literacy may be interpreted as the new mathematics standard grade. Let me be emphatic about this. It is not! Mathematical literacy is a different kind of mathematics, not a different, lower level of mathematics. Mathematical literacy will be at least as demanding as mathematics to teach and certainly as challenging for pupils to learn.

\section{Understanding of course content}

The other questions in the questionnaire revolved around students' understanding of the course content and their experience of learning mathematics literacy. Teachers who were positive about their classroom experience and understanding of the course constituted $52 \%$ of respondents, while $48 \%$ did not understand the course and found it difficult, e.g. "Dit is moeilik vir ons wat nie wiskunde verstaan nie" [It is difficult for us who do not understand mathematics] or "Mathematical Literacy for Teaching is a bit more difficult to understand." Another example of the teachers' dissatisfaction with the course, which I found interesting and contradictory, is that one teacher felt uncomfortable with the fact that the course was not "school based". He or she states, seemingly after consulting those teachers who teach mathematics: "Die Wiskunde wat ons hier doen, sê die Wiskunde opvoeders is nie skool gebaseerde nie. Hulle sê dit is baie moeilik." [The Mathematics teachers say that the Mathematics that we do here is not school based. It is very difficult.]

An example of a response I regard as positive is the following: "Relevant. Besides the fact that after a long day of seven periods. Teaching. Loaded administration duties, $54 \mathrm{~km}$ of travelling, the classes are enrichfull [sic] and enjoyable." I also regard the following as a positive response:
"Ek geniet die klasse en leer elke keer iets nuut. Sommige van die werk is moeilik, maar met oefeninge kom ek by. Wiskunde word gebied deur metodes wat ek nog nie gesien en dis alles baie nuut vir my." [I enjoy the classes and learn something new each time. Part of the work is difficult but with exercises I manage. Mathematics is presented through methods which I have not seen before and everything is very new to me.]

\section{Evaluation of the course}

One question related to the students' attitude towards the assignments and the final examination. All students were positive about the assignments because the assignments "give(s) you more time to reflect on what you were doing in class".

Six of the teachers $(30 \%)$ were concerned that they did not have the time to do the assignments because of the pressure of being full-time teachers. On the examination paper only four students $(20 \%)$ felt that the paper was fair and not difficult. The rest felt that the paper was difficult and that the lecturers had misled them with regard to the scope of the examination paper that they were given. One student put it this way: "Standard of paper was too high - reminded me of old regime where papers were set to 'catch you out'- Very stressful \& too little time. We were misled with the scope."

Whilst generally students felt that the examination itself was difficult, they did not have the view that the course was difficult as evidenced by nearly $50 \%$ who saw the course as fair and enjoyable. In the examination, there was one little misunderstanding about the time allocated for the examination paper but all students passed the final examination paper, after only five students who did not obtain the requisite pass mark qualified for re-examination.

\section{Reflections on the findings}

\section{Reasons for registering for the course}

From the teachers' responses to the question why they registered for the course on mathematical literacy, I identified two types of reasons, namely, pedagogical and strategic reasons. Pedagogical reasons are reasons given by the teachers that have to do with their view of their teaching responsibilities and the furtherance of their professional and qualification status in the subject. Strategic reasons are reasons that have to do with job security. From reading their responses I deduced that strategic reasons were also disguised as pedagogical reasons.

Reflecting on the reasons articulated by these teachers on why they chose to do the course, one 
finds that some of these teachers had a strategic objective in joining the course, which did not necessarily coincide with the Education Department's vision for requesting them to register for the course. They felt that if they obtained a qualification in mathematical literacy, it would make them key teachers in the department and consequently could not easily be declared in excess and hence would not be redeployable. This would achieve the objective articulated so bluntly by $15 \%$ of the teachers that they joined the course to secure their jobs in the department. These teachers have a particular understanding of the Education Department's policy of rationalisation that certain categories of teachers like mathematics teachers cannot easily be redeployed. More than a third of the teachers saw themselves fulfilling the vision of the Department of Education, in other words, responding to the needs of the department to address a curriculum development objective.

A quarter of the teachers had the view that their engagement with the course would enable them to teach mathematics, in other words, they had the perception that mathematical literacy prepares them to teach mathematics.

From this one can deduce that these teachers did not see any distinction between mathematics and mathematical literacy. At present there are debates about the compatibility or incompatibility of mathematics and mathematical literacy (See Madison, http://www.aacu.org). Madison (2005: np) proposes a solution to this dilemma by suggesting an integration of what he terms "formal mathematics and QL (Quantitative Literacy) mathematics through more contextual teaching, thereby making mathematics more apparently relevant to contemporary society". Hence these teachers, although they might not be aware of the debates, are spot on in assuming that by being students of mathematical literacy, they would gain enough mathematical knowledge and pedagogical content knowledge to enable them to teach more than mathematical literacy. The challenge is for teacher educators to be aware that, to teach mathematical literacy, one also needs to use mathematical tools and simultaneously acquaint teachers with this knowledge. There is also an advocated position that mathematical literacy and mathematics can be integrated. Madison (2005: np) argues for the need for this integration and states:

[These] pedagogical changes, admittedly more difficult, include increased extraction of abstractions from examples, better understanding of effective contextual teaching practices and more attention to research results about how people learn.

One can infer that the $25 \%$ of respondents who state that they registered for the course to teach mathematics form part of those teachers who do not teach mathematics at their schools because it is highly unlikely that those who already teach mathematics would see their participation in the mathematical literacy course as a springboard to teach the mathematics they already teach. These teachers saw their participation in the course as an opportunity to gain enough subject content knowledge in mathematical literacy to make it possible for them to teach mathematics. The implication of this perception is that the content of mathematical literacy is the same as the content of mathematics or, as argued above, it is possible to integrate the two. Others decided to satisfy a personal need to improve their qualifications by enrolling for a course when an opportunity presented itself.

If one looks at the profile of teachers in terms of their mathematics qualifications, one finds that the vast majority (i.e. 85\%) have passed grade 12 mathematics although the majority $(75 \%)$ do not teach mathematics. One can thus understand that the time period that has passed since they did grade 12 can explain their perception of the course as difficult. Nevertheless, there is almost a 50/50 split between those who regard the course as difficult and those who regard it as manageable and hence it is also understandable that an equal number of teachers do not regard the course as difficult. It is informative to note that $30 \%$ of these teachers are qualified mathematics teachers even though not all of them teach the subject. The statement that the subject matter of the mathematical literacy class is not school based is strange, coming from teachers who teach under the new Curriculum 2005 of the South African National Education Department, which professes to encourage creativity in teachers as "the designers of the curriculum" (DoE, 2000: 13) in its norms and standards document for educators. Perhaps, their perception that the course in mathematical literacy is not school based might come from the fact that very few textbooks on mathematical literacy have been written and these teachers have not yet come across those textbooks which have already been written.

Their comments might also be a consequence of their not being used to the kind of creativity that the lecturers exercised in coming up with contextual examples in the teachers' class activity and written work. 


\section{Monde Mbekwa}

\section{Common sense understanding of mathematical literacy}

Generally what has been gauged from the responses of these teachers is that the majority of the respondents have an understanding of mathematical literacy as an easier version of mathematics. This is understandable because mathematical literacy as a school subject is still in its infancy and mathematics educators still have no clear-cut answers on what mathematical literacy is or what it should be. Nevertheless, there is some agreement that mathematical literacy has to do with real life application of mathematics.

The question that one can pose is - if a citizen can read his or her municipal account and can decide on the basis of the reading on the water or electricity meter that the municipality has overcharged him or her or that when the weather forecaster indicates that the probability of rain is $30 \%$, that it does not mean that it will drizzle but that there is a small chance of rain given the prevailing weather conditions - does it mean that the citizen is mathematically literate? The teachers' conception of mathematical literacy then represents spontaneous views not tempered by interrogation of the literature on the subject - a literature which is still seeking answers. Coincidentally this conception of mathematical literacy, which these teachers have, concurs with some ideas on mathematical literacy that are found in the literature.

\section{Experiencing and evaluating the course}

The issue of the alleged difficulty of the subject is also an issue, which raises more questions than answers because it has not been established what the teachers mean by difficult or what aspects of the course they found difficult. Is it the content which they found difficult or is it the activity or process approach whereby they were required to investigate scenarios that would lead them to understand contextually embedded mathematical concepts?

\section{Conclusion}

At the time of finalising this paper, 29 of the initial 35 teachers who registered for the course had completed their final assessments for the course and it is highly likely, judging from their previous academic performance, that all of them will graduate with the ACE: Mathematical Literacy qualification in September 2006.
From this study one can consider the exercise of taking these teachers through this course over two years and the high retention rate of $83 \%$ at one institution as evidence of the success of this project, albeit on a small scale.

\section{References}

Adler, J. (2003). Global and local challenges of teacher development. In J. Adler \& Y. Reed (Eds.), Challenges of Teacher Development: An investigation of take-up in South Africa. Pretoria: Van Schaik.

Brombacher, A. (2005, March 1). Mathematical Literacy Vital for Life Today. Cape Town: Cape Times.

Department of Education. (2003). National Curriculum Statement: Grades 10 - 12 (General): Mathematical Literacy. Pretoria: Department of Education.

Department of Education. (2000). Norms and Standards for Educators. Government Gazette No. 20844. Pretoria: Department of Education.

International Programme Committee for ICMI Study 14. (2002). Study 14: Applications and Modelling in Mathematics Education Discussion Document. Educational Studies in Mathematics, 51, 149-171.

Jablonka, E. (2003). Mathematical Literacy. In A. Bishop, C. Clements, J. Keitel, J. Kilpatrick \& F.K.S. Leung (Eds.), Second International Handbook of Mathematics Education (pp 103142). Dordrecht: Kluwer Academic Publishers.

Madison, B. L. Two Mathematics: Ever the Twain Shall Meet? Retrieved May 2, 2005, from http://www.aacu.org.

Mathematical Council of the Alberta Teachers' Association. Mathematical Literacy...an idea to talk about. Retrieved May 2, 2005, from www.mathteachers.ab.ca/MCATA.

Organisation for Economic Co-operation and Development (OECD). (Ed). (2001). Knowledge and Skills for Life. First Results from the OECD Programme for International Student Assessment (PISA) (2000). Paris: OECD.

Pandor, Naledi (2004). The Release of Senior Certificate Examination Results by the Minister of Education. Retrieved May 2, 2005, from www.education.gov.za.

Romberg, T. A (2001). Mathematical Literacy: What Does it Mean for School Mathematics (pp 5-8). Wisconsin School News. Available at: http://www.wcer.wisc.edu. Retrieved May 7, 2005. 